Mgr Agnieszka Jabłońska*

\title{
KOMPETENCJE KADR WSPÓŁPRACY ZAGRANICZNEJ POLSKICH WOJEWÓDZTW NA TLE STANDARDÓW MIĘDZYNARODOWYCH
}

Ostatnia dekada, jak chyba żadna poprzednia znaczona jest internacjonalizacją różnych aspektów życia społeczno-gospodarczego w Polsce. ${ }^{247}$ Wynika to z aktywizacji Polski na forum międzynarodowym, a przede wszystkim z członkostwa w Unii Europejskiej. Skutkiem tego procesu jest nie tylko rozwój polityki zagranicznej państwa, ale przede wszystkim ekspansja polskich podmiotów pozapaństwowych na forum międzynarodowym. ${ }^{248}$ Obok aktywności organizacji pozarządowych, ${ }^{249}$ przedsiębiorstw ${ }^{250}$ czy nawet osób fizycznych ${ }^{251}$ daje się zaobserwować istotny rozwój współpracy międzynarodowej jednostek samorządu terytorialnego. W szczególności należy zwrócić uwagę na postępującą aktywność międzynarodową województw samorządowych. ${ }^{252}$ Działalność ta $\mathrm{z}$ jednej strony opiera się na dorobku prawnym Rady Europy, ${ }^{253}$ a z drugiej strony wynika z oddolnych działań samorządów wojewódzkich, które poprzez współpracę międzynarodową starają się realizować swoje zadania. Swoistym „odrodzeniem” okazało się tu jednak powierzenie samorządom wojewódzkim zadań związanych z wdrażaniem unijnej polityki spójności ${ }^{254}$ Wzrosło w związku z tym zatrudnienie oraz zintensyfikowała się mobilność międzynarodowa kadr urzędów marszałkowskich. Proponowana reforma polityki spójności

Kierownik Biura Fundacji Prawo i Partnerstwo, specjalista ds. projektów, doradca zawodowy. Współpracownik Ośrodka Prawa Zarządzania Funduszami Europejskimi przy Wydziale Prawa UwB, prowadzi ćwiczenia z prawa międzynarodowego publicznego.

247 R. Kuźniar, Globalizacja, geopolityka i polityka zagraniczna, [w:] „Sprawy Międzynarodowe” 2000 nr 1.

248 Wpisuje się to w proces ekspansji tzw. „non-state actors” na forum międzynarodowe. Zob. B. Mielnik, Kształtowanie się pozapaństwowej podmiotowości w prawie międzynarodowym, Wrocław 2008.

249 Zob. M. Dudkiewicz, G. Makowski, Współpraca między organizacjami pozarządowymi i administracją samorządową. Problemy, wyzwania i rekomendacje, Warszawa 2011.

250 Patrz: K. Karski, Osoba prawna prawa wewnętrznego jako podmiot występujący przed Europejskim Trybunałem Praw Człowieka, [w:] Ochrona praw człowieka w świetle prawa RP, pod red. S. Pikulskiego, Olsztyn 2002.

251 Patrz: M. Perkowski, Podmiotowość prawa międzynarodowego współczesnego uniwersalizmu w złożonym modelu klasyfikacyjnym, Białystok 2008.

252 Zob. W. Sługocki, Polityka regionalna w Polsce jako przestrzeń aktywności samorządu terytorialnego, Warszawa 2009.

253 Zwłaszcza Europejska Karta Społeczna, Dz.U. z 1999 r. Nr 8, poz. 67.

254 Tu obserwujemy proces niejako włączania organów samorządowych w system instytucjonalny sensu largo albowiem zadania UE powierzone zostały organom administracji samorządowej i/lub ich jednostkom organizacyjnym. 
na lata 2014-2020 zakłada wzrost znaczenia regionów (a zatem i polskich województw) ${ }^{255} \mathrm{w}$ tym zakresie. Mając to na względzie można założyć, że kadry urzędów marszałkowskich odpowiadające za współpracę zagraniczną pełnią szczególnie ważną rolę, której znaczenie najprawdopodobniej jeszcze wzrośnie. W tej sytuacji bardzo istotne znaczenie mają kompetencje tych kadr. W pierwszej kolejności należy ustalić, jakie kompetencje są kluczowe dla obsługi współpracy zagranicznej województwa.

\section{Wybrane międzynarodowe standardy administracji}

Przystąpienie Polski do Unii Europejskiej dało możliwość obserwacji praktyki administracji publicznej innych krajów członkowskich. Jednak spostrzeżenia te wskazują na brak uniwersalnych rozwiązań. Można oczekiwać stopniowego ujednolicania lub raczej upodabniania się do siebie stosowanych rozwiązań, jednak nie można liczyć na łatwy transfer doświadczeń innych krajów do polskich realiów. Warte podkreślenia jest to, że korzystanie z owego doświadczenia oznacza raczej „zaczerpnięcie inspiracji dla stworzenia własnych rozwiązań” niż łatwe „wprowadzenie sprawdzonych w praktyce rozwiązań”, gdyż administracja publiczna w Polsce znacznie różni się od swoich odpowiedników w innych krajach. Odpowiednie wykorzystanie tych inspiracji wymaga uwzględnienia istoty administracji publicznej, jej celów działania, modelu organizacji oraz stanu obecnego stosowanych rozwiązań. ${ }^{256}$

W związku z rozszerzaniem zakresu zadań administracji, co jest bardzo widoczne w ostatnich dziesięcioleciach, w tym zwłaszcza zadań o charakterze gospodarczym, społecznym, a także międzynarodowym doszło do poważnych przeobrażeń w dziedzinie zawodowego przygotowania kandydatów na wyższych urzędników. Administracja wszędzie zatrudnia (jak to od dawna miało miejsce we Francji) specjalistów $\mathrm{z}$ różnych dziedzin. Odrodziły się po długim czasie odrębne studia administracyjne. Większość krajów wzoruje się pod tym względem na Francji, gdyż właśnie tam powołano w 1945 r. Narodową Szkołę Administracji (Ecole Nationale d'Administration), znaną pod skrótową nazwą ENA. ${ }^{257}$ Utworzył ją Charles de Gaulle, którego głównym celem w tym okresie była odbudowa państwa ze zniszczeń wojennych, do czego potrzebna była wysoka jakość służby cywilnej mogąca sprostać temu zadaniu. ${ }^{258}$ ENA jest podporządkowaną urzędowi premiera uczelnią o charakterze (zasadniczo) podyplomowym. Absolwenci ENA uzyskują tytuł administratora cywil-

Oficjalna strona internetowa Ministerstwa Rozwoju Regionalnego, tryb dostępu: http://www.mrr.gov.pl/fundusze/ fundusze_europejskie_2014_2020/programowanie_2014_2020/strony/glowna.aspx, dnia 12.12.2012 r.

T. Rostkowski, Strategiczne zarządzanie zasobami ludzkimi w administracji publicznej, Warszawa 2012, s. 13.

M. Kulesza, M. Niziołek, Etyka służby publicznej, Warszawa 2010, s. 88.

Służba cywilna w wybranych państwach demokratycznych, Stowarzyszenie Absolwentów Krajowej Szkoły Administracji Publicznej, Warszawa 1995. 
nego, który daje prawo do objęcia wszystkich wyższych urzędów w administracji. Jest to szkoła, która kształci elity administracyjne i polityczne. Ukończenie szkoły otwiera absolwentom drogę do wysokich urzędów państwowych. Cechą ENA jest dokonywanie selekcji spośród kandydatów pod kątem określonych cech psychofizycznych, na które zwraca się większą uwagę niż na wiedzę kandydata. Przy wyborze najwyżej punktowane mają być: motywacja kandydata, jego predyspozycje intelektualne oraz umiejętność przekonywania i słuchania. ${ }^{259}$ ENA posłużyła za wzór dla Wielkiej Brytanii, gdzie utworzono w 1969 r. Szkołę Służby Państwowej (Civil Service College). ${ }^{260}$ Wzorzec ENA brany był pod uwagę przy tworzeniu w Polsce Krajowej Szkoły Administracji Publicznej (KSAP).

Formuła Europejskiej Szkoły Administracji ${ }^{261}$ i jej geneza sięgają jeszcze roku 2000, kiedy rozpoczęto głębsze doświadczenia z prowadzeniem szkoleń dla całego korpusu urzędniczego Unii Europejskiej. Utworzona w 2005 r. jako specyficzny rodzaj szkoły, będący odrębną, europejską akademią dyplomatyczną, której zadaniem i rolą jest organizowanie odpowiednich szkoleń z wykorzystaniem sieci współpracujących ze sobą krajowych akademii dyplomatycznych. Za swe pierwsze zadanie obrała przeprowadzenie szkoleń w określonych obszarach dla najważniejszych urzędników Unii. Kursy szkoły mają charakter otwarty dla urzędników/pracowników wszystkich instytucji unijnych. Dzięki temu ESA pomaga i przyczynia się do rozciągnięcia wspólnych wartości, promując lepsze zrozumienie prawa europejskiego wśród sztabu urzędniczego UE. Dzięki szkoleniom Szkoła ma także powodować wzrost osiągnięć w zakresie rozwoju gospodarczego w skali makro. Szkolenia unijnych dyplomatów odbywają się w ścisłej współpracy, w grupach treningowych (szkoleniowych) wszystkich instytucji UE, a to dlatego, by uniknąć sytuacji powtarzania tych samych szkoleń przez poszczególnych urzędników.

Europejski Kodeks Dobrej Administracji jest niewątpliwie interesującym dokumentem zasługującym na uznanie, mogącym przyczynić się do lepszego działania organów administracji. Uchwalony 6 września 2001 r. przez Parlament Europejski „Europejski Kodeks Dobrej Administracji” (KDA) został opracowany przez Ombudsmana Unii Europejskiej Jacoba Södermana. Parlament Europejski zalecił we wrześniu 2001 r. stosowanie KDA w organach i instytucjach Unii. Można więc traktować KDA jako zbiór standardów przydatnych także poza granicami Unii do oceny funkcjonowania administracji. Nie ma żadnych powodów przemawiających przeciwko uznaniu standardów zawartych w KDA za przydatne do wyznaczania obowiązków polskiej administracji albo do interpretacji prawa. Ma to znaczenie dla

259 E. Ura, Prawo urzędnicze, Warszawa 2007, s. 279.

260 Ibidem, s. 230.

261 Europejska Szkoła Administracji (ang. European Administrative School, wł. Scuola Europea Di Amministrazione) - oficjalny skrót: EAS - została utworzona 26 stycznia 2005 r., więcej www.europa.eu/eas/ 
przystosowania codziennych kontaktów obywatela z urzędem do wymogów stawianych w systemie instytucjonalnym Unii Europejskiej. ${ }^{262}$

\section{Specyfika współpracy międzynarodowej}

Wskutek rozwoju systemu międzynarodowego jego uczestnikami, oprócz państw, stawały się także podmioty pozapaństwowe. Współcześnie określa się stosunki międzynarodowe jako - dziedzinę zajmująca się badaniem relacji zachodzacych pomiędzy różnymi podmiotami uczestniczacymi $w$ polityce międzynarodowej (państwa, organizacje międzynarodowe, organizacje pozarzadowe, samorzady lokalne, obywatele). ${ }^{263}$

Zasadą współczesnych stosunków międzynarodowych jest współpraca, o czym mówi art. 1 Karty Narodów Zjednoczonych - doprowadzenie ,...do współdziałania międzynarodowego $w$ rozwiąywaniu zagadnień o charakterze gospodarczym, społecznym, kulturalnym lub humanitarnym, jak również popierania i zachęcania do poszanowania praw człowieka i podstawowych wolności dla wszystkich, bez względu na rase, płeć, język lub wyznanie... ". ${ }^{264}$ Współpraca wymaga szeregu wysiłków. Po pierwsze - poznania świata zewnętrznego, czyli wiedzy o świecie zewnętrznym, o partnerach, identyfikacji wspólnych obszarów zainteresowań, potencjalnej wymiany, kooperacji. Po drugie - współpraca domaga się szczególnej komunikacji, zazwyczaj w języku obcym (często obcym dla obu stron, np. w języku angielskim), a także dyplomacji, która w stosunkach międzynarodowych jest kluczowa.

\section{Kadry współpracy zagranicznej polskich województw}

Podstawy prawne współpracy zagranicznej realizowanej przez województwa określają art. 172 pkt 2 Konstytucji Rzeczypospolitej Polskiej ${ }^{265}$ oraz art. 75-77, art. 18 pkt 13 i 14 i art. 41 pkt 5 Ustawy z dnia 5 czerwca 1998 roku o samorządzie województwa. ${ }^{266} \mathrm{Na}$ podstawie ww. przepisów współpraca zagraniczna województwa prowadzona jest zgodnie z prawem wewnętrznym, polityką zagraniczną państwa i jego międzynarodowymi zobowiązaniami, w granicach zadań i kompetencji województwa.

Kadry współpracy zagranicznej polskich województw są to - po pierwsze - komórki sensu stricto odpowiedzialne za współpracę zagraniczną (np. Departament

\footnotetext{
262 J. Świątkiewicz, Europejski Kodeks Dobrej Administracji, tekst i komentarz o zastosowaniu kodeksu w warunkach polskich procedur administracyjnych, Warszawa 2005, s. 7.

263 T. Łoś-Nowak, Stosunki międzynarodowe teorie - systemy - uczestnicy, Wrocław 2000, s. 29.

264 Karta Narodów Zjednoczonych, Statut Międzynarodowego Trybunału Sprawiedliwości, San Francisco 1945 r. (Dz.U. z 1947 r. Nr 23, poz. 90).

265 Konstytucja Rzeczypospolitej Polskiej z dnia 2 kwietnia 1997 r., Dz.U. z 1997 r. Nr 78, poz. 483.

266 Ustawa z dnia 5 czerwca 1998 r. o samorządzie województwa, Dz.U. 2001 r. Nr 142, poz. 1590 z późn. zm.
} 
Współpracy z Zagranicą i Promocji). ${ }^{267}$ Komórki niniejsze koordynują i monitorują współpracę międzynarodową samorządu województwa ze strukturami samorządu regionalnego w innych krajach oraz z międzynarodowymi podmiotami, zrzeszeniami regionalnymi i sieciami międzynarodowymi. Dbają o wizerunek publiczny samorządu województwa za granicą oraz współdziałają w zakresie działań związanych z promocją województwa na arenie międzynarodowej prowadzoną przez urząd marszałkowski.

Tabela 1. Zadania Referatu Współpracy z Zagranicą na przykładzie woj. podlaskiego ${ }^{268}$

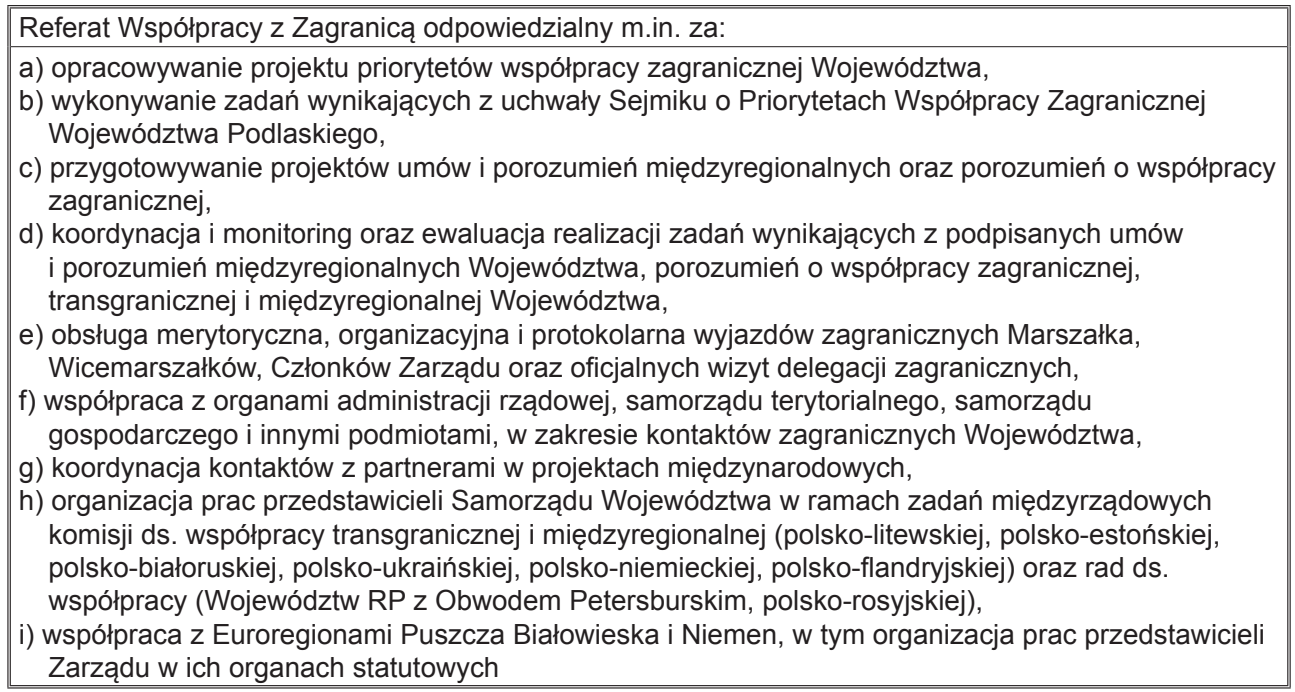

Po drugie - są to pracownicy przedstawicielstw zagranicznych (np. zamiejscowe stanowisko pracy - Biuro Regionalne Województwa Podlaskiego w Brukseli), ${ }^{269}$ do zadań których należy w szczególności reprezentowanie interesów województwa i kształtowanie pozytywnego wizerunku regionu na forum instytucji europejskich, m.in. poprzez działania informacyjne i promocyjne, kontakty robocze z przedstawicielami regionów partnerskich. Kolejnym ważnym zadaniem jest opracowywanie (zebranie, analiza, ocena i rekomendacje) bieżących informacji uzyskanych w instytucjach Unii Europejskiej ważnych z punktu widzenia interesów gospodarczych województwa, w tym uzyskiwanie informacji o unijnych źródłach i możliwościach finansowania projektów w województwie. Biuro w Brukseli moni-

267 Nazwa Departamentu na przykładzie województwa podlaskiego, w innych województwach nazewnictwo może się różnić, Załącznik do Uchwały NR 53/647/2011 Zarządu Województwa Podlaskiego, z dnia 13 września $2011 \mathrm{r}$.

268 Opracowanie własne na podstawie: Załącznika do Uchwały NR 53..., op. cit., s. 56.

269 Załącznik do Uchwały NR 53..., op. cit., s. 57. 
toruje także prace Komitetu Regionów i stowarzyszeń europejskich zrzeszających regiony, jednocześnie pomaga $\mathrm{w}$ organizacji staży i praktyk $\mathrm{w}$ instytucjach europejskich dla osób zainteresowanych współpracą z województwem.

Istotną rolę $\mathrm{w}$ zakresie aktywności międzynarodowej województw pełnią departamenty odpowiedzialne za wdrażanie funduszy europejskich (np. Departament Europejskiego Funduszu Społecznego lub Departament Zarządzania Regionalnym Programem Operacyjnym). ${ }^{270}$ Kadra w nich zatrudniona jest odpowiedzialna m.in. za współpracę i uczestnictwo w negocjacjach z rządem i Komisją Europejską.

Współpracę międzynarodową obsługują de facto także pojedynczy pracownicy (m.in. dyrektorzy departamentów, pracownicy biura Marszałka, kancelarii Zarządu) z pozostałych jednostek odpowiedzialni w pewnym stopniu za współpracę zagraniczną w swoich działach np. koordynowanie wizyt zagranicznych Marszałka, współpraca z Departamentem Współpracy z Zagranicą i Promocji w przygotowywaniu zagranicznych podróży Wicemarszałków i Członków Zarządu, zapewnienie organizacyjnej, medialnej i protokolarnej obsługi oficjalnych wizyt krajowych i zagranicznych Wicemarszałków i Członków Zarządu.

Ci ostatni wraz ze Skarbnikiem i Sekretarzem tworzą kadrę kierowniczą województwa (Zarząd, Sekretarz, Skarbnik). Do zadań Zarządu Województwa należy $\mathrm{m}$.in. organizowanie współpracy ze strukturami samorządu regionalnego $\mathrm{w}$ innych krajach i z międzynarodowymi zrzeszeniami regionalnymi, podróże zagraniczne, reprezentowanie województwa za granicą. ${ }^{271}$

W świetle powyższego wyliczenia kadry współpracy zagranicznej polskich województw tworzą „,mozaikę” osób, stanowisk i kompetencji formalnych. Tym trudniejsza wydaje się zatem identyfikacja jednolitych kompetencji kluczowych dla tych kadr.

\section{Kluczowe kompetencje kadr współpracy zagranicznej polskich województw}

Kompetencje określają związek między naszymi indywidualnymi zdolnościami i cechami osobowości a cechami wymaganymi do sprawnego wykonywania zadań zawodowych. ${ }^{272} \mathrm{Na}$ prace nad standaryzacją kompetencji pracowników administracji samorządowej należy patrzeć w kontekście poprawy funkcjonowania urzędów samorządowych. Urzędy samorządu terytorialnego, podobnie jak organizacje działające zarówno we wszystkich gałęziach gospodarki, jak i we wszelkich dziedzinach życia człowieka, dążą do podnoszenia jakości świadczonych przez siebie usług. Sys-

270 Ibidem, s. 29

271 Ibidem

272 Definicja oparta na dorobku Międzynarodowej Organizacji Pracy, więcej na: www.ilo.org. 
temowe podejście do doskonalenia jakości zapewnia Model CAF, ${ }^{273}$ który pozwala osiągnąć najwyższe standardy zarządzania, stosowane przez administrację publiczną w Unii Europejskiej. Model CAF (Powszechny Model Oceny) dostarcza ocenę jakości administracji publicznej oraz kompleksowo diagnozuje funkcjonowanie urzędu i wskazuje kierunki jego rozwoju. Może być wykorzystywany w rządowych i samorządowych podmiotach sektora publicznego. Jako najważniejsze zalety owego modelu wymienia się kompleksowe podejście, uznawanie specyfiki funkcjonowania organizacji, a także udoskonalanie wyników działalności oraz benchmarking pomiędzy organizacjami.

W Polsce funkcjonuje standard kwalifikacji zawodowych pracownika samorządu, opracowany w projekcie Phare 2000 „Krajowy System Szkolenia Zawodowego". Standard kwalifikacji zawodowych w tym ujęciu to norma minimalnych wymagań kwalifikacyjnych dla danego zawodu ujętego w klasyfikacji zawodów i specjalności, opisany jako układ umiejętności, wiadomości i cech psychofizycznych niezbędnych do wykonywania zadań zawodowych.

W pracach nad standaryzacją kompetencji ważny jest także profil europejskiego pracownika, który został określony przez Organizację Współpracy Gospodarczej i Rozwoju (OECD) ${ }^{274}$ w późnych latach 90-tych. Zgodnie z określeniem OECD istnienie europejskiej przestrzeni administracyjnej oznacza, że administracja publiczna jest zarządzana i funkcjonuje na podstawie wspólnych europejskich zasad, reguł i regulacji jednolicie stosowanych na określonym terytorium. Kompetencje kluczowe zawierają się w europejskiej strategii Life Long Learning, czyli „Uczenia się przez całe życie”, której głównym celem jest budowanie konkurencyjnej, dynamicznej i opartej na wiedzy gospodarki poprzez inwestowanie w zasoby ludzkie. Obejmuje on 8 kompetencji ogólnych, pozwalających na efektywne wykonywanie zawodu (m.in. zdolność uczenia się, kompetencje interpersonalne, obywatelskie i informatyczne, przedsiębiorczość, porozumiewanie się w językach: ojczystym i obcym). Dzięki badaniom przeprowadzonym także wśród europejskich pracodawców zbiór kompetencji został dostosowany do realiów naszego kontynentu. Definicja, którą przyjęto, zakłada, że kompetencje są zbiorem wiedzy, umiejętności i postaw.

273 Model CAF (Common Assessment Framework ) - czyli Powszechny Model Oceny jest modelem samooceny i doskonalenia przeznaczonym dla jednostek administracji publicznej. Model CAF jest rezultatem współpracy prowadzonej od 1998 roku przez kraje Unii Europejskiej oraz prac analitycznych prowadzonych przez Europejską Fundację Zarządzania Jakością (EFQM), Wyższą Szkołę Nauk Administracyjnych Speyer'a (Deutsche Hochschule fur Vervaltungswissenschaften Speyer) - Niemcy oraz Europejski Instytut Administracji Publicznej (European Institute of Public Administration - EIPA) w Maastricht - Holandia. W 2000 r., podczas Europejskiej Konferencji Zarządzania Jakością w Administracji Publicznej w Lizbonie, Dyrektorzy Generalni Administracji Publicznej oficjalnie zalecili CAF do stosowania przez organizacje administracyjne krajów Unii. Więcej na: www.caf. com.pl.

274 Organizacja Współpracy Gospodarczej i Rozwoju - OECD (Organisation for Economic Co-Operation and Development). OECD jest międzyrządową organizacją gospodarczą, powołaną do życia w 1961 r. na mocy Konwencji Paryskiej, podpisanej w 1960 r. Jest bezpośrednią sukcesorką Organizacji Europejskiej Współpracy Gospodarczej (OEEC), powstałej w 1948 r. w celu odbudowy Europy ze zniszczeń wojennych w ramach realizacji Planu Marshalla. Siedziba organizacji znajduje się w Paryżu, więcej na: www.oecd.org. 
Poniżej przedstawione zostały kluczowe kompetencje w ich oryginalnym nazewnictwie oraz ich uzasadnienie na podstawie zaleceń Parlamentu Europejskiego i Rady:

Tabela 2. Kluczowe Kompetencje ${ }^{275}$

\begin{tabular}{|c|c|}
\hline 1. Zdolność uczenia się & $\begin{array}{l}\text { Kompetencja ta zawiera wiedzę dotyczącą potrzeb w zakresie uczenia } \\
\text { się, preferowanego sposobu nabywania wiedzy, analizę słabych } \\
\text { i mocnych stron oraz zdolność identyfikowania dostępnych szans } \\
\text { rozwoju. }\end{array}$ \\
\hline $\begin{array}{l}\text { 2. Kompetencje } \\
\text { interpersonalne, } \\
\text { międzykulturowe } \\
\text { i społeczne }\end{array}$ & $\begin{array}{l}\text { Te aspekty zachowania jednostki, które pozwalają na jej aktywne } \\
\text { uczestnictwo w życiu społecznym i zawodowym. Ważne będzie } \\
\text { tu więc rozumienie zasad postępowania i reguł zachowania w różnych } \\
\text { społeczeństwach oraz środowiskach. Dużą rolę odgrywa tu empatyczna } \\
\text { postawa. Ten zbiór kompetencji pozwala pracownikowi łatwo } \\
\text { zaaklimatyzować się w nowym otoczeniu. }\end{array}$ \\
\hline $\begin{array}{l}\text { 3. Kompetencje } \\
\text { obywatelskie }\end{array}$ & $\begin{array}{l}\text { Opierają się one na znajomości pojęć i struktur w życiu społecznym } \\
\text { i politycznym, zaangażowaniu w życie publiczne, aktywnym } \\
\text { uczestnictwie w działaniach społeczności lokalnych. Jest to } \\
\text { kompetencja szczególnie u pracowników sektora administracji } \\
\text { publicznej. }\end{array}$ \\
\hline 4. Przedsiębiorczość & $\begin{array}{l}\text { Zamiana pomysłów w działanie. Jest to bardzo szeroki obszar } \\
\text { obejmujący m.in. kreatywność, innowacyjność, umiejętność } \\
\text { podejmowania skalkulowanego ryzyka, wyznaczanie celów, planowanie } \\
\text { i realizacja swoich planów, zarządzanie projektami. Stanowi } \\
\text { ona niezbędną bazę do nabywania kompetencji związanych już } \\
\text { z konkretnymi przedsięwzięciami. }\end{array}$ \\
\hline 5. Ekspresja kulturalna & $\begin{array}{l}\text { Twórcze wyrażanie swoich opinii, idei, doświadczeń i uczuć. Obejmuje } \\
\text { ona znajomość zagadnień i umiejętność korzystania z różnych środków } \\
\text { wyrazu, np. muzyka, sztuka teatralna, literatura, sztuki wizualne, } \\
\text { media, jak również zdolność odniesienia własnych punktów widzenia } \\
\text { w zakresie twórczości i ekspresji do opinii innych oraz zainteresowanie } \\
\text { życiem kulturalnym. }\end{array}$ \\
\hline $\begin{array}{l}\text { 6. Porozumiewanie się } \\
\text { w języku ojczystym } \\
\text { i w językach obcych }\end{array}$ & Dominującymi językami są język angielski, niemiecki i francuski. \\
\hline $\begin{array}{l}\text { 7. Kompetencje } \\
\text { matematyczne } \\
\text { i podstawowe } \\
\text { kompetencje naukowo- } \\
\text { techniczne }\end{array}$ & $\begin{array}{l}\text { Dużą rolę przywiązuje się tutaj do logicznego i przestrzennego myślenia } \\
\text { oraz wyrażania swoich idei z zastosowaniem wzorów, modeli, tabel czy } \\
\text { wykresów. Kompetencja charakterystyczna } \\
\text { i dominująca wśród środowisk biznesowych. } \\
\text { Kompetencje naukowo-techniczne pozwalają na wykorzystanie } \\
\text { istniejącej już wiedzy i metodologii podczas wykonywania zadań } \\
\text { zawodowych. }\end{array}$ \\
\hline $\begin{array}{l}\text { 8. Kompetencje } \\
\text { informatyczne }\end{array}$ & $\begin{array}{l}\text { Skuteczne posługiwanie się technologiami społeczeństwa } \\
\text { informacyjnego w różnych aspektach (praca, rozrywka, komunikacja). } \\
\text { Korzystanie z komputera i Internetu podczas zbierania, analizowania, } \\
\text { edytowania, prezentowania oraz wymiany informacji. Porozumiewanie } \\
\text { się za pośrednictwem Internetu, nawiązywanie kontaktów, budowanie } \\
\text { swojej sieci kontaktów, współpraca w sieci. Praca w każdej firmie } \\
\text { nierozłącznie wiąże się już z wykorzystaniem komputera i Internetu. }\end{array}$ \\
\hline
\end{tabular}

275 Opracowanie własne na podstawie: Zalecenia Parlamentu Europejskiego i Rady nr 2006/962/WE z dnia 18 grudnia 2006 r. w sprawie kompetencji kluczowych w procesie uczenia się przez całe życie (Dz.U. L 394 z 30.12.2006) i portalu praca.pl. 
Wydaje się, że przedstawione powyżej kompetencje są dostosowane do realiów polskiej administracji publicznej. A jak jest w praktyce? Obecnie jestem na etapie analizowania wyników badań statystycznych i empirycznych. Wstępnie (a priori) wydaje się, że przy zatrudnianiu nie analizuje się owych kompetencji szczegółowo, a nawet jeśli, to najwyżej pośrednio, bez systematycznego, uporząakowanego podejścia. Ostateczną weryfikację tego zagadnienia próbuję przeprowadzić w ramach przygotowywanej rozprawy doktorskiej. Wyniki będę starała się przedstawiać w kolejnych publikacjach. Podnoszenie jakości usług administracji publicznej stanowi ciągle jeszcze otwartą kwestię i wyznacza ważny kontekst dla realizacji prac nad uformowaniem profili kompetencji ogólnych pracownika samorządu, które stanowić mogą istotny etap i punkt wyjścia do systematycznego i metodycznego doskonalenia kompetencji urzędników (w tym kadr współpracy zagranicznej), co w konsekwencji powinno przełożyć się na odpowiednią, satysfakcjonującą współpracę międzynarodową i rozwój regionów. 


\section{THE COMPETENCY OF POLISH PROVINCES PERSONNEL RESPONSIBLE FOR INTERNATIONAL COOPERATION IN COMPARISON TO INTERNATIONAL STANDARDS}

The last decade is characterized by the internationalization of various socio economic aspects of life in Poland. It is caused by the increase of Poland's activity at international forum and especially thanks to the membership in the European Union.

The proposed cohesion policy reform for the period 2014-2020 assumes increasing importance of regions in this matter. It can be assumed that the marshal offices personnel responsible for international cooperation plays a special role, the importance of which will rise. In this perspective the competency of such personnel is significant.

The first part of the paper discusses selected standards of public administration (National School of Administration, European Administrative School, The European Code of Good Administration Behaviour) and the specificity of international cooperation. Subsequently, the subject of personnel responsible for international cooperation of Polish provinces is addressed. In the conclusion, key competencies of the personnel are identified.

Keywords:

Competency, personnel, public administration, international cooperation 